удК 349.4

DOI https://doi.org/10.32837/apdp.v0i83.133

С. В. Савченко

\title{
ПРАВОВА ОХОРОНА ЗЕМЕЛЬ ДЛЯ ДАЧНОГО БУДІВНИЦТВА
}

Постановка проблеми. Землі, які використовуються для дачного будівництва, виступають окремим складником земель рекреаційного призначення, що входять до самостійної категорії земель України. Генеральна схема планування території України, затверджена Законом України від 7 лютого 2002 року, передбачає використання земель, на яких розташовані цінні рекреаційні ресурси, для рекреаційних цілей, а також розміщення загальної площі земель рекреаційного призначення.

Землі рекреаційного призначення відповідно до ст. 162 Земельного кодексу України [1] підлягають особливій охороні. Діючі нормативно-правові акти щодо правового режиму охорони земель для дачного будівництва лише фрагментарно регламентують окремі аспекти цього правового інституту, який практично ще перебуває на стадії формування. Так, Земельний кодекс України (ч. 4 ст. 52) містить відсильну норму до спеціального закону, який мав би врегульовувати особливості використання і охорони всіх земель рекреаційного призначення, у тому числі й тих, які використовуються для дачного будівництва. Проте, спеціальний закон до цих пір, на жаль, не прийнято.

Такий стан речей зумовлює необхідність звернутися до загальних норм земельного законодавства України, присвячених охороні земель для дачного будівництва, та приписів, що регулюють суміжні правові відносини. Саме підхід синтезу у застосуванні загальних приписів і норм, що врегульовують окремі аспекти використання земель для дачного будівництва, виступає визначальним не тільки для захисту прав власника чи землекористувача відповідних земель, а й охорони відповідних земель.

Аналіз останніх досліджень і публікацій. Незважаючи на те, що окремі представники земельно-правової науки (А.Г. Бобкова, Т.В. Лісова, Л.А. Самусенко, Т.Б. Саркісова, М.М. Скляр, М.В. Шульга та іншіi) вже проводили характеристику правового режиму земель для дачного будівництва та розглядали окремі аспекти цієї проблематики, особливості правової охорони земельних ділянок для дачного будівництва системно не досліджені до цих пір.

Метою статті є здійснення правового аналізу правовідносин у сфері охорони земель для здійснення індивідуального дачного будівництва, встановлення прогалин у чинному національному законодавстві та формулювання власних висновків і пропозицій із цієї проблематики.

Виклад основного матеріалу дослідження. Питання, яке стосується охорони земель, в тому числі і для дачного будівництва на землях рекреаційного призначення в умовах сьогодення актуалізується. Використання цих земель під дачну забудову має створювати умови для забезпечення відпочинку і задоволення потреб населення у збереженні, відновленні та розвитку життєвих сил людей (фізичних, психічних, духовних та інших) [2, с. 16, 17]. Дачне будівництво (як індивідуаль-

(C) C. В. Савченко, 2019 
не, так і колективне) здійснюється в межах відповідних земельних ділянок, які використовуються для зведення об'єктів стаціонарної рекреації. В даному випадку йдеться про реалізацію громадянами права рекреаційного природокористування, тобто природокористування з метою їх відпочинку та оздоровлення [3, с. 23-25].

Дачне будівництво здійснюється переважно біля водойм або на землях, зайнятих лісами, оскільки ці землі зазвичай виконують передовсім рекреаційні функції при розташуванні стаціонарної рекреації. Використання цих земель під дачну забудову потребує належної охорони, яка виступає обов'язковим елементом їх правового режиму. Під правовим режимом земель рекреаційного призначення в юридичній літературі пропонується розуміти встановлені нормами земельного права суб'єктивні земельні права та юридичні обов'язки суб'єктів по відношенню до земель рекреаційного призначення, порядок управління використанням і їхньою охороною, правової охорони земель рекреаційного призначення, що спрямовані на забезпечення їх раціонального використання [4, с. 11].

Землі рекреаційного призначення віднесені законодавцем до земель, які особливо охороняються. Це стосується в тому числі й земельних ділянок, які використовуються під дачну забудову. За приписами ст. 50 Земельного кодексу України землі рекреаційного призначення використовуються передовсім для забезпечення відпочинку та оздоровлення населення, в тому числі для дачного будівництва. Використання таких земель згідно із законом зумовлює необхідність будівництва на відповідних земельних ділянках дачних будинків як стаціонарних об'єктів рекреації.

Доречно зазначити, що наведений підхід законодавця до визначення правового режиму використання та охорони земель для дачного будівництва суттєво відрізняється від режиму земель, призначених, наприклад, для індивідуального та колективного садівництва. В останньому випадку йдеться, по-перше, про використання земель в якості засобу виробництва (закладки саду чи винограднику), тобто земель сільськогосподарського призначення, а, по-друге, на садових земельних ділянках громадяни можуть, а не зобов’язані будувати садові будинки.

Існують й інші правові відмінності дачних і садових земельних ділянок, передбачені чинним законодавством - різний максимальний розмір земельних ділянок, неоднаковий обсяг прав та обов'язків громадян, які використовують ці земельні ділянки. Водночас садову і дачну земельну ділянку поєднує те, що вони, маючи різне цільове призначення, використовуються в тому числі під забудову об'єктами нерухомості. За таких умов основним завданням охорони земель для дачного будівництва виступає передовсім забезпечення збереження їх рекреаційних властивостей, які складають підгрунтя режиму нормального відпочинку та оздоровлення людей.

В основу цього напряму охорони земель, що використовуються для дачного будівництва, має бути покладено дотримання встановлених законом обмежень і заборон, які мають забезпечувати належну охорону даних земель. На цих землях ст. 52 Земельного кодексу України забороняє діяльність, що перешкоджає або може перешкоджати використанню їх за призначенням, а також негативно впливає або може вплинути на природний стан земель рекреаційного призначення.

Як бачимо, законодавець забороняє господарську діяльність, яка негативно впливає на стан довкілля, в тому числі й на землі рекреаційного призначення, що 
перешкоджає використанню їх за цільовим призначенням, або створює можливість, небезпеку негативного впливу як на навколишнє середовище, так і на землі рекреаційного призначення. Йдеться, наприклад, про зміну ландшафту та інші протиправні дії, які негативно впливають чи можуть вплинути на стан земель рекреаційного призначення. Порушення закріплених законом обмежень і заборон щодо використання земель рекреаційного призначення свідчить про порушення вимог, які стосуються охорони цих земель. Для осіб, винних у порушенні наведених вимог, наступають негативні наслідки у вигляді притягнення до юридичної відповідальності.

Складність у реалізації декларованого державою права на отримання громадянами ділянок для дачного будівництва виражається у зв'язку з необхідністю об'єднання багатьох компонентів для досягнення такої мети. Йдеться, зокрема, про ініціативність територіальної громади, бажання окремих громадян отримати ділянки у конкретній місцевості, вдале місце розташування таких ділянок для подальшого підведення необхідних комунікацій (доріг, електропостачання), вирішення питання про можливість зміни цільового призначення земельних ділянок та іншого.

Слід наголосити, що в основу використання земель для дачного будівництва закон покладає експлуатацію їх в якості територіальної бази, просторового майданчика площею в межах 0,10 га, яка підлягатиме забудові. 3 цієї точки зору визначальними є положення ч. 3 ст. 48 Закону України «Про охорону земель» [5], відповідно до приписів якої забудова земельних ділянок, що надаються для містобудівних потреб, здійснюється після виникнення права власності чи права користування, у тому числі на умовах оренди, земельною ділянкою, у порядку, передбаченому законом. Це свідчить про те, що законом закріплено пріоритет вирішення земельно-правових питань перед забудовою земельних ділянок. Ця норма одночасно є додатковою гарантією убезпечення від самовільного зайняття земельної ділянки та самочинної забудови земельної ділянки, а також слугує базою для реалізації трендової нині вимоги щодо першочергового проектування майбутнього будівництва належним видом містобудівної документації.

Основним нормативно-правовим актом у сфері регулювання містобудівної діяльності є Закон України «Про регулювання містобудівної діяльності» [6]. Закон визнає наявність містобудівної документації в якості необхідної передумови відведення земельних ділянок для містобудівних потреб та здійснення подальшого будівництва на них.

Враховуючи те, що розміщення дачних будинків відповідно до Державних будівельних норм України як єдиного типу будівель, будівництво яких здійснюється на земельних ділянках для дачного будівництва можливе лише за межами населеного пункту, - містобудівною документацією, яка повинна визначити планувальну організацію та розвиток відповідної території, виступає виключно детальний план території. Зазначений вид містобудівної документації введено разом із прийняттям та введенням у дію чинного Закону України «Про регулювання містобудівної діяльності». Незважаючи на вітчизняну практику «поступової обкатки» новел у законодавстві, блок правових приписів, які стосуються детального планування, виглядає досить прогресивним. 
Відповідно до ст. 19 Закону України «Про регулювання містобудівної діяльності» детальний план території визначає: 1) принципи планувально-просторової організації забудови; 2) червоні лінії та лінії регулювання забудови; 3) функціональне призначення, режим та параметри забудови однієї чи декількох земельних ділянок, розподіл територій згідно з будівельними нормами, державними стандартами і правилами; 4) містобудівні умови та обмеження (у разі відсутності плану зонування територіі) або уточнення містобудівних умов та обмежень згідно із планом зонування території; 5) потребу в підприємствах і закладах обслуговування населення, місце їх розташування; 6) доцільність, обсяги, послідовність реконструкції забудови; 7) черговість та обсяги інженерної підготовки території; 8) систему інженерних мереж; 9) порядок організації транспортного і пішохідного руху; 10) порядок комплексного благоустрою та озеленення, потребу у формуванні екомережі; 11) межі прибережних захисних смуг і пляжних зон водних об'єктів (у разі відсутності плану зонування території). Детальний план території безпосередньо обгрунтовує доцільність розміщення на конкретній території об'єктів дачного будівництва, можливість ефективно задовольнити потреби громадян у відпочинку, визначає ступінь можливого і допустимого впливу на навколишнє природне середовище майбутнього будівництва.

На практиці детальним планом території може передбачатись допустимий рівень зміни природного ландшафту: а) знесення та/або створення нових зелених насаджень, зміна рельєфу, питання зняття верхнього родючого шару; б) вплив на землю у зв'язку із підведенням комунікаційних мереж; в) доцільність включення до екологічної мережі прилеглих територій прибережних захисних смуг, лісових ділянок (така можливість прямо передбачена пунктом «д» ч. 1 ст. 5 Закону України «Про екологічну мережу України» [7] та ч. 1 ст. 50 Закону України «Про охорону земель» [5]). Наведені положення безпосередньо стосуються охорони земель, які використовуються для дачного будівництва. Такий стан речей породжує унікальне явище, за якого регулювання інституту охорони земель для дачного будівництва можливе не на основі спеціального законодавства (яке на теперішній час просто відсутнє), а забезпечується дією норм, предметом регулювання яких є суміжний інститут, - правовий інститут регулювання містобудівної діяльності.

Повертаючись до вимог Закону України «Про регулювання містобудівної діяльності», варто зазначити, що детальний план території за межами населеного пункту розглядається і затверджується відповідною районною державною адміністрацією протягом 30 днів з дня його подання. Прийняття розробленого у встановленому порядку детального плану території виступає публічною процедурою, у доступі до якої не може бути відмовлено представникам громади. Цим положенням забезпечується легітимність (тобто підтримка більшістю населення громади) прийнятої планувальної документації.

Легітимність має забезпечуватися органом контролю за використанням та охороною земель. Для виконання зазначених функцій законодавцем такому органу надано широкі повноваження. Так, статтею $17^{1}$ Закону України «Про охорону земель» визначено, що до повноважень центрального органу виконавчої влади, який реалізує державну політику із здійснення державного нагляду (контролю) у сфері 
охорони навколишнього природного середовища у галузі охорони земель належать: 1) здійснення державного нагляду (контролю) за дотриманням законодавства про використання та охорону земель щодо консервації деградованих і малопродуктивних земель; 2) збереження водно-болотних угідь; 3) виконання екологічних вимог при наданні у власність і користування, у тому числі в оренду, земельних ділянок; 4) здійснення заходів щодо запобігання забрудненню земель хімічними та радіоактивними речовинами, відходами, стічними водами; 5) дотримання режиму використання земель природно-заповідного та іншого природоохоронного призначення, а також територій, що підлягають особливій охороні; 6) дотримання екологічних нормативів із питань використання та охорони земель; 7) установлення та використання водоохоронних зон і прибережних захисних смуг, а також щодо дотримання режиму використання їх територій; 8) ведення будівельних, днопоглиблювальних робіт, видобування піску і гравію, прокладення кабелів, трубопроводів та інших комунікацій на землях водного фонду; 9) звернення до адміністративного суду щодо застосування заходів реагування у вигляді обмеження чи зупинення (тимчасово) або припинення діяльності підприємств і об'єктів незалежно від їх підпорядкування та форм власності відповідно до закону, якщо їх експлуатація здійснюється з порушенням законодавства про охорону земель; 10) подання позовів про відшкодування шкоди і втрат, заподіяних внаслідок порушення законодавства України про охорону земель. При цьому реалізація зазначених функцій можлива як на стадії затвердження детального плану території, так і після відведення ділянок для забудови і здійснення їх використання.

Висновки. На підставі аналізу норм земельного законодавства у сфері правової охорони земель для індивідуального дачного будівництва можна резюмувати, що основним завданням охорони земель для дачного будівництва виступає передовсім забезпечення збереження їх рекреаційних властивостей. Це стосуватиметься тих властивостей, які забезпечують режим нормального відпочинку. В основу цього напряму охорони земель, що використовуються для дачного будівництва, має бути покладено дотримання встановлених законом обмежень і заборон, які мають забезпечувати належну охорону цих земель.

\section{Jimepamypa}

1. Земельний кодекс України від 25.10.2001 р. № 2768-III. Відомості Верховної Ради України. 2002. № 3-4. Ст. 27.

2. Бобкова А.Г. Правовое обеспечение рекреационной деятельности. Донецк : Юго-Восток, 2000. $308 \mathrm{c}$.

3. Самусенко Л.А. Право рекреационного природопользования / Белорус. гос. ун-т. Минск : Право и экономика, $2014.142 \mathrm{c.}$

4. Скляр М.М. Правовий режим земель рекреаційного призначення: автореф. дис. на здоб. наук. ступ. канд. юрид. наук. Київ, 2012. 24 с.

5. Про охорону земель: Закон України від 19.06.2003 р. № 962-IV. Відомості Верховної Ради України. 2003. № 39. Ст. 349.

6. Про регулювання містобудівної діяльності: Закон України від 17.02.2011 p. № VI. Відомості Верховної Ради України. 2011. № 34. Ст. 343.

7. Про екологічну мережу в Україні: Закон України від 24.06.2004 p. № 1864-IV. Вiдомості Bepховної Ради України. 2004. № 45. Ст. 502. 


\section{Анотація}

Савченко С. В. Правова охорона земель для дачного будівництва. - Стаття.

Статтю присвячено дослідженню сучасних проблем правового регулювання суспільних відносин у сфері охорони земель для здійснення індивідуального дачного будівництва. Метою наукової статті визначено здійснення правового аналізу правовідносин у сфері охорони земель для здійснення індивідуального дачного будівництва, встановлення прогалин у чинному національному законодавстві та формулювання власних висновків і пропозицій із цієї проблематики.

У науковій статті досліджено збереження рекреаційних властивостей таких земель. Землі, які використовуються для дачного будівництва, виступають окремою складовою земель рекреаційного призначення, що входять до самостійної категорії земель України. У статті наголошується на дотриманні засад стабільності та прогнозованості відносин у цій сфері, що виступають складовими принципу «правової визначеності». Дачне будівництво, як індивідуальне, так і колективне, здійснюється в межах відповідних земельних ділянок, які використовуються для зведення об'єктів стаціонарної рекреації. У цьому випадку йдеться про реалізацію громадянами права рекреаційного природокористування, тобто природокористування з метою їх відпочинку та оздоровлення.

Визначено проблеми подвійного, інколи потрійного правового режиму використання та охорони земель для дачного будівництва та вибору ділянок для такої діяльності. Доведено, що основним завданням охорони земель для дачного будівництва виступає передовсім забезпечення збереження їх рекреаційних властивостей. Це стосуватиметься тих властивостей, які забезпечують режим нормального відпочинку. В основу цього напряму охорони земель, що використовуються для дачного будівництва, має бути покладено дотримання встановлених законом обмежень і заборон, які мають забезпечувати належну охорону цих земель.

Обгрунтовано тезу про те, що прийняття розробленого у встановленому порядку детального плану території виступає публічною процедурою, у доступі до якої не може бути відмовлено представникам громади. Цим положенням забезпечується легітимність (тобто підтримка більшістю населення громади) прийнятої планувальної документації.

Для досягнення поставленої мети наукової статті використовувалися загальнонаукові й спеціально-наукові методи пізнання: діалектичний, формально-логічний (догматичний), логіко-юридичний.

Ключові слова: індивідуальне дачне будівництво, земельні правовідносини, оренда землі, договір оренди землі, земельне право.

\section{Summary}

Savchenko S. V. Legal protection of land for suburban construction. - Article.

The article is devoted to the research of contemporary problems of legal regulation of social relations in the field of land protection for the implementation of individual cottage construction. In a scientific article has been investigated conservation of recreational properties of such lands. The purpose of the scientific article is to determine the legal analysis of legal relations in the field of land protection for the implementation of individual cottage construction, to identify gaps in the current national legislation and to formulate their own conclusions and proposals on this issue.

Lands used for cottage construction are a separate component of recreational land belonging to the independent category of land in Ukraine. Cottage construction, both individual and collective, is carried out within the respective land plots used for the erection of the objects of in-patient recreation. In this case, it is about the realization by citizens of the right of recreational use of nature, that is, nature use for the purpose of their rest and recovery.

Have been identified the problems of dual, sometimes triple legal regime of land use and protection for country construction and selection of sites for such activity. It is proved that the main task of protecting land for country construction is primarily to ensure the preservation of their recreational properties. It seems that this will apply to those properties that provide a mode of normal rest. The basis for this area of protection of land used for summer construction should be based on compliance with the statutory restrictions and prohibitions that should ensure proper protection of these lands. Has been grounded the thesis that the adoption of a detailed territory plan developed in accordance with the established procedure is a public procedure, which cannot be denied to the community. This provision provides legitimacy (ie support for the majority of the community) of the planning documentation adopted.

To achieve the goal of the scientific in the article has used general scientific and specially scientific methods of cognition: dialectical, formal-logical (dogmatic), logical and legal.

Key words: individual suburban construction, land legal relations, land lease, land lease agreement, land law. 